\title{
Returns and Volatility Spillover between Islamic and Conventional Indexes: Evidence from Selected Emerging Asian Markets
}

\author{
Muhammad Azhar Khan ${ }^{1}$, Ajid ur Rehman ${ }^{2 *}$ \\ ${ }^{1}$ MS (Finance), Riphah International University, Islamabad, and FCMA, ICMAP, Islamabad, Pakistan \\ 2 Assistant Professor in the Faculty of Management Sciences, Riphah International University, \\ Islamabad, Pakistan
}

\section{Keywords}

Return and Volatility Spillover Islamic and Conventional Indexes

Emerging Stock Markets

Islamic Finance

Received: 22 March 2018

Accepted: 24 October 2018

\begin{abstract}
This study is an attempt to explore whether explicit Islamic (Sharīah based) investment criteria have any impact on return and volatility spillover from Islamic to conventional indexes and vice-versa. It pertains to five selected emerging Asian markets i.e., China, India, Indonesia, Malaysia and Pakistan. The return and volatility spillover has been measured in this study using the spillover index approach introduced by Diebold and Yilmaz (2012), built on the idea of Forecast Error Variance (FEV) decomposition in the generalized Vector Autoregressive (VAR) framework. The study finds that Islamic indexes are recipients of volatility spillovers from conventional indexes both in the selected Muslim minority countries (China and India) as also in countries where Muslims are in majority (Indonesia and Pakistan). Moreover, during normal periods, mean returns of conventional indexes in both categories of countries are better than that of Islamic indexes. During crises, however, Islamic indexes performed comparatively better than their conventional counterparts in Indonesia and Pakistan (Muslims majority countries), thus providing a diversification opportunity. Findings of this study have implications for policy makers, fund managers and individual investors for better understanding the diversification opportunities both in in normal business environment and in crisis period. Moreover, faith-based investors and portfolio managers may not get the desired benefit of diversification linked to investing in Islamic assets alone; therefore, they should include other classes of assets in their portfolios to mitigate risk.
\end{abstract}

KAUJIE Classification: L4, L43, V12

JEL Classification: E32, O16

(C) 2018 JIBM. All rights reserved.

\section{INTRODUCTION}

Return and volatility spillover among various stock markets is a significant research area because of its importance for policy makers, fund managers and individual investors in rela-

\footnotetext{
${ }^{*}$ Corresponding author: Ajid ur Rehman

†Email: ajid.rehman@riphah.edu.pk
} 
tion to managing risk and getting better returns by way of diversification. From traditional finance theory, it is known that returns can be enhanced by investing in different stocks of various industries, markets and regions provided that these markets are not subject to the same level of risk factors (Abbas, Khan, \& Shah, 2013; Datta, Rajagopalan, \& Rasheed, 1991). In case various stock markets are correlated, then investors may not find the desired benefits in terms of returns. This necessitates the study of returns and volatility spillover among various markets. Volatility in the stock prices is echoed by the rate of growth of such macro variables in economy which also play their part in changing the volatility of the stocks. The more economic interdependence between markets, the more contagious they would be in turmoil period (Hkiri, Hammoudeh, Aloui, \& Yarovaya, 2017). In today's business environment, information flow is fast, therefore, rate of change of prices of stocks is also very quick. This becomes riskier when returns and volatility shocks from one market or region travel to another interdependent markets or regions in no time. . As opined by Dymski (2005) financial crisis can incessantly spread from one region to another, thus badly affecting the international economy. Moreover, inexpensive information flow has reduced the isolation of regional markets from international markets (Singh, Kumar, \& Pandey, 2008).

Earlier studies conducted on spillover of stock indexes provide mix empirical evidence of interrelation among different stock indexes around the globe. The empirical work by King, Sentana, and Wadhwani (1990) for studying the inter-relationship of the major world stock indexes, by using data of sixteen stock markets for the period 1970-1988, revealed no integration of international stock markets. It also found that apart from macroeconomic factors, there are other unexplainable factors which are important in understanding the variations in stocks returns. On the other hand, Kim and Rogers (1995) detected presence of volatility transmission from two renowned developed markets of USA and Japan towards Korea after adopting liberalization policies. However, Bekaert and Harvey (1997) found decrease in aspects of volatility in nearly all countries which undergone liberalization, with study sample consisting of twenty emerging stock markets. $\mathrm{Ng}$ (2000) studied volatility spillover effects from Japan and USA to the Pacific-Basin; its empirical results mostly revealed trivial magnitudes of volatility transmission, as measured through regional and global factors. Empirical study conducted by Corradi, Distaso, and Fernandes (2012) produced evidence of volatility spread between China, Japan, UK, and USA stock markets. Many studies are available which can be presented as evidence of interrelationship between foreign exchange and stock markets (e.g., Aydemir \& Demirhan, 2009; Kutty, 2010; Tabak, 2006; Zhao, 2010). Kumar (2013) empirically found volatility spillover between equity and currency markets, in both directions, in IBSA countries (i.e., India, Brazil and South Africa).

In recent some years, empirical studies have been conducted on the Islamic indexes and their return and volatility spillover towards conventional indexes. To cite a few of them are Majdoub and Mansour (2014), who studied the conditional correlations of all USA markets with five Islamic markets (Indonesia, Malaysia, Pakistan, Qatar and Turkey). Similarly, Ajmi, Hammoudeh, Nguyen, and Sarafrazi (2014) found both linear and nonlinear substantial relation between Dow Jones Islamic Market (DJIM) index, and the S\&P stock market 
indexes for the United States, Europe and Asia. Further, Rizvi, Arshad, and Alam (2015) attempted to investigate market co-movements in Islamic and mainstream equity markets across USA and Asia Pacific. Ahmad, Rais, and Shaik (2016) examined the issues of directional interdependence and financial performance of Sharī'ah-screened Islamic equity finance with conventional benchmarks.

This study has examined the recent dimensions in the return and volatility spillover in the Islamic finance perspective, namely how the stringent conditions of Sharī'ah influence the performance of stock market; how consistent Islamic finance market behaves; is there any evidence of transmission of shock between Islamic and conventional Indexes; and whether volatility spillover in countries with Muslims majority (Indonesia and Pakistan) is same as compared to the countries where non-Muslims are in majority (China and India)? Answers to these questions are important for policy makers, portfolio managers and individual investors, whether looking for diversification opportunities or simply going for Islamic stocks owing to their religious beliefs.

Past studies on the return and volatility spillover between Islamic stock market and conventional counterparts are not conclusive. There are many studies in which effects of return and volatility spillover are investigated, e.g., between developed stock markets of different regions (Kim \& Rogers, 1995); between developed and developing countries indexes (Majdoub \& Mansour, 2014); between Islamic and conventional regional indexes of a single country (Jebran, Chen, \& Tauni, 2017); or effects of change in prices of currencies, gold \& oil on the stock market (e.g., Tabak, 2006). However, measurement of return and volatility spillover between Islamic and conventional indexes of five selected emerging Asian markets, namely China, India, Indonesia, Malaysia and Pakistan, is a research gap yet to be explored empirically. This study, to the best of my knowledge, is first of its kind to investigate spillover in these emerging Asian markets, and any impact of the religious faith on return and volatility transmission in Muslim majority and Muslim minority countries. The religious belief is taken as appropriate aspect while studying the interconnection of Islamic and conventional markets (Akhtar, Ali, \& Sadaqat, 2011). It is also important to find intensity of volatility spillover between Islamic and conventional indexes, while these markets are still in emerging phase. This also has been analysed whether Sharí ${ }^{-}$ah screening criteria play any role in minimizing the transmission of return and volatility between Islamic indexes and their conventional counterparts. The methodology introduced recently by Diebold and Yilmaz (2012) has been used to enhance the robustness of the results.

Based on above arguments this study has three-fold objectives: firstly, it is desired to know whether the presence of Sharī'ah investment criteria has any impact on returns and volatility spillover from Islamic to conventional indexes and vice-versa; secondly, whether the investors and fund managers get the benefit of diversification by splitting their investments in Islamic and conventional indexes; and lastly, any difference in transmission of shocks among countries with majority of population as Muslim (Indonesia and Pakistan), and the countries where majority are non-Muslims (China and India).

Findings of net volatility spillovers analysis discloses that Islamic indexes are recipients of volatility spillovers from conventional indexes both in countries where non-Muslims are 
in majority (China and India) and in countries where Muslims are in majority (Indonesia and Pakistan). Such results were previously reported by Ajmi et al. (2014), Hammoudeh, Mensi, Reboredo, and Nguyen (2014) and Rizvi et al. (2015). Moreover, during the overall sample period, means returns of conventional indexes are better than Islamic indexes. During the GFC of 2008, however, Islamic indexes comparatively performed better than their conventional counterparts in Indonesia and Pakistan where Muslims are in majority. These findings are partly in line with the studies of Ho, Rahman, Yusuf, and Zamzamin (2014) and Miniaoui, Sayani, and Chaibi (2015), thus providing a little diversification opportunity during the turbulent periods. Total return spillover score is more than total volatility spillover, which suggests that in the sample countries, shock transmission is more by real returns than mere by transmission of news.

The remainder of this paper is arranged as follows: Section 2 provides a detailed review of literature, Section 3 discusses the methodology employed to measure the returns and volatility spillover, Section 4 provides results and discussion of this study and section 5 discusses the conclusion and various policy implications.

\section{LITERATURE REVIEW}

\section{Historical Perspective of Return and Volatility Spillover}

Transmission of information between stock markets can be assessed through return and volatility spillover. The extent of interdependency across various stock markets has long been studied and the research work on stock price movements across international stock markets can be traced back to 1970s. Initially, the decrease in stocks value of USA in 1970s is explained by Pindyck (1984, as cited by Theodossiou \& Lee, 1993) by stating that it was owing to increase in volatility. Bollerslev, Engle, and Wooldridge (1988) also found that the conditional volatility of stock market returns considerably changed their anticipated value. Eun and Shim (1989) have also opined that shocks or innovations in the USA stock market are swiftly transferred to other markets of the globe; however, shocks or innovations occurred in other stock markets have very little impact on stock market of USA. Hamao, Masulis, and $\mathrm{Ng}$ (1990) investigated the daily price volatility spillover of USA, UK and Japan stock markets and observed volatility shocks transmitted from the USA to Japan and UK, and also from the UK to Japan. Indrawati (2002) tested dynamic relation of macro monetary economic variable and capital market indexes and reported that Indonesian capital market are integrated to USA capital market. Study conducted by Balasubramanyan and Premaratne (2003) used ten years (1992-2002) day-to-day return figures and concluded that there was substantial volatility transmission from Singapore stock market to Hong Kong, Japan, and USA. Many other studies have found the empirical evidence of information transmission between stock markets (Aydemir \& Demirhan, 2009; Cheung \& Ng, 1993; Corradi et al., 2012; King \& Wadhwani, 1990; Kutty, 2010; Susmel \& Engle, 1994; Tabak, 2006; Theodossiou \& Lee, 1993; Zhao, 2010).

On the other hand, study conducted by Baillie and DeGennaro (1990) found no interconnection between stock market returns and volatility. Similarly, empirical work by King et al. 
(1990) revealed no integration among global stock markets. They also found that apart from macroeconomic factors, there are other factors which are not explainable, but are important in understanding the changes in stock returns. A similar outcome of interrelation between stock markets' return and volatility is supported by French, Schwert, and Stambaugh (1987).

\section{Islamic Finance and Indexes}

Islam being a religion of more than 1.8 billion souls of this globe, about $24 \%$ of the worldwide population ${ }^{1}$, is the second-largest religion of the world, after Christianity. However, it is the fastest-growing religion and with this growth it may become world's largest religion by the end of this century as per Pew Research Center estimate (Lipka, 2017). Islamic finance denotes a financial system which has to be coherent with the Shari'ah maxims (Islamic principles), and reflects the human well-being and justice (Schoon, 2008). The Islamic finance is based on real economic trade. Society wellbeing is taken care of by ideologies of social justice, the environment and kindness, for better investment products and financial markets (Hassan \& Mahlknecht, 2011). While, the conventional financial system takes the economic and financial aspects of a transaction only, Islamic finance adds ethical and social facets (El Khamlichi, Sarkar, Arouri, \& Teulon, 2014). Islamic finance is not only showing unprecedented growth in Muslim countries but also continues its growth trend in Muslim communities of non-Muslim countries (Van Greuning \& Iqbal, 2008). The Global Financial Crises (GFC) of 2008 has generated excessive attentiveness in ascertaining Islamic financeand, as opined by Hassan and Mahlknecht (2011), an honest implementation of Islamic finance could mitigate or eliminate such crisis.

The striking feature of Islamic finance is prohibition of "interest" which is prevalent in the conventional finance. The prohibition of riba is found in several verses of the Holy Qur'an, particularly the verses 2:275-278, which also indicate a principle to explain rib $\bar{a}$ involved in loans and debts [for details, see Ayub, 2007]. The logic for the injunction on riba (interest) has been discussed by many Islamic scholars (e.g., Ayub, 2007; Elgari, 2003; Iqbal \& Mirakhor, 2011; Obaidullah, 1999). To explain the system of Islamic finance, a large number of papers and books have been written (e.g., Archer \& Karim, 2007; Ayub, 2007; Billah, 2003; Elgari, 2003; Iqbal \& Mirakhor, 2011; Obaidullah, 1999; Rosly, 2008).

The beginning of Islamic indexes was in the late nineties. Dow Jones Islamic Market index (DJIM) was introduced in 1999, FTSE Global Islamic Index Series (GIIS) in 1998, Morgan Stanley Capital International (MSCI) World Islamic Index in 2007, and S\&P/TSX 60 Sharī'ah Index (TXSI.TS) in 2009. Regional index providers for Sharī'ah compliant companies started to join the market, to name a few are Bahrain in 2015, India in 2010, Indonesia in 2000, Malaysia in 2015, Pakistan in 2009, and Turkey in 2011.

\section{Screening Criterion for Sharī'ah Compliant Stock Company}

As regards the prohibitions in the Sharī'ah, all Islamic stock indexes follow common ground. For selection of companies for valid investment, however, the Sharī'ah scholars of respective indexes may have minor differences. Normally, two step screening process consisting

\footnotetext{
${ }^{1}$ www.pewresearch.org
} 
of qualitative and quantitative factors are used i.e., business activity of the company and its financial ratios (El-Khamlichi et al., 2014). First screening process is used to exclude the companies like conventional financial institutions, insurance companies, casinos, pork products, alcohol, and tobacco (Derigs \& Marzban, 2009). There may be instances when a company's main activity is Sharí'ah compliant, but it conducts some other prohibited transactions (El-Gamal, 2006; Yaqubi, 2000), so the second criteria is applied which is the quantitative part. This process uses some financial ratios, and some limits are set. When the ratios are within the tolerable limits, the company is said to be Shar'̄'ah compliant. Additionally, a purification process is also applied, in which a percentage of dividend is paid out to the charity. Juristic opinion of Sharī'ah scholars may vary over time and from one region to another based on the tolerance level in the market (Ayub, 2007; Bin Mahfouz \& Ahmed, 2014). Some scholars see these transformations as an active sign of flexibility with the provisions of Islamic Shari' $a$, as its purpose is to help Muslims in the emerging disputes and environments pertaining to the Sharah elucidation. The aim of Accounting and Auditing Organization of Islamic Financial Institutions' (AAOIFI) Sharī'ah standards is the synchronization of the different Islamic finance practices across the major markets ${ }^{2}$. The study will utilize the MSCI's Islamic and conventional indexes data.

\section{Past Studies on Return and Volatility Spillover of Islamic Indexes}

With increasing trend of liberalization, globalization and the introduction of Islamic indexes at international and national levels, the discussions on contagion and decoupling hypothesis have gained momentum. The contagion hypothesis suggests that the impact of volatility spillovers across markets is growing during crisis periods which limits the benefits of portfolio diversification. The decoupling hypothesis states that emerging markets were less affected by the crisis (Aggarwal as cited in Hkiri et al., 2017). In literature, both types of studies are found which support either decupling or contagion hypothesis. Most Islamic indexes fall in the emerging categories of MSCI; hence, it is vital to recognize how Islamic indexes interact with their conventional counterparts, either in emerging markets or in regions where Muslims are in majority.

Study conducted by Majdoub and Mansour (2014) did not find an absolute evidence of spillover across USA market and a sample of five Islamic emerging markets (Indonesia, Malaysia, Pakistan, Qatar and Turkey). Similarly, empirical work by Sahar and Shah (2017) did not find any absolute indication of spillover from developed markets of USA, UK and Japan to the countries having majority population as Muslims (i.e., Egypt, Indonesia, Jordan, Kuwait, Lebanon, Morroco, Pakistan, Tunisia and Turkey). However, several studies provide empirical foundations of inter-relationship between Islamic and conventional stock markets. For example, substantial positive and negative return spillover from China to Islamic indexes of India, Indonesia, Malaysia, Korea and Thailand is found (Majdoub \& Ben Sassi, 2017). Empirical study of Hammoudeh et al. (2014) also establishes that the international Islamic stock market of Dow Jones unveils key dependence on three main international conventional stock markets of Asia, Europe, and United States. Recent study

${ }^{2} \mathrm{http}: / /$ aaoifi.com/mission/?lang=en 
by Jebran, et al. (2017) shows substantial long-term and short-term relationship between Islamic index and their conventional counterpart in Pakistan.

Empirical work on Islamic stock indexes also reveals that its performance is better than conventional counterparts in turbulent periods. For example, Ho et al. (2014) conducted a comparative study on Islamic and conventional stock markets by measuring their riskadjusted performance and detected that Islamic indexes outperformed conventional indexes during turbulent times; but the results were indecisive for the normal time periods. Somewhat similar inference was made by Miniaoui et al. (2015) after investigating the performance of Islamic and conventional stock markets of the Gulf Cooperation Council (GCC) countries (i.e., Bahrain, Kuwait, Oman, Qatar, Saudi Arabia and UAE) in the wake of financial crisis of 2008. They found that returns in all countries, except Bahrain, remained unaffected; however, the volatility spillover to indexes of Bahrain, Kuwait and UAE was significant, and insignificant on other GCC countries.

Literature provides both types of studies which either support decoupling of Islamic stock markets from conventional indexes or go in favour of contagious hypothesis. Decoupling of Islamic indexes form conventional counterpart during crises period is supported by the empirical work by Ahmad et al. (2016), Dewandaru, Rizvi, Masih, Masih, and Alhabshi (2014), and Hkiri et al. (2017). On the other hand, several studies rejecting the decupling hypothesis in normal circumstances can be cited (e.g., Ajmi et al., 2014; Hammoudeh, et al., 2014; Jebran et al., 2017; Shahzad, Ferrer, Ballester, \& Umar 2017).

Owing to the resilient trait of Islamic finance, consisting of ban on interest, gambling, speculation and extreme uncertainty, one can expect it to outperform conventional finance and show more resistance during crises period, however, the results of the past studies are not conclusive about transmission of either return or volatility between Islamic indexes and their conventional counterparts, so more empirical work is needed in this domain. This study is also an endeavor to find more empirical evidence for better understanding the phenomenon of contagion or decoupling of the Islamic indexes, particularly in emerging markets.

\section{DATA AND METHODOLOGY}

\section{Data Collection and Sample}

MSCI daily data of Islamic and conventional indexes for five selected emerging Asian markets of China, India, Indonesia, Malaysia and Pakistan has been used for the time period from 31-May-2002 to 29-September-2017 which results in to 4001 number of observations. The study sample countries are carefully chosen, containing emerging Asian markets for seeing the effect of decoupling or contagion hypothesis. China and India have been selected being the major players in East Asian region having major population as non-Muslims, while Indonesia and Pakistan have been selected for having major population as Muslims; the two markets, along-with Malaysia have been selected owing to their practical initiatives taken for introducing Islamic indexes at regional levels and providing investment opportunities to faith-based investors. Particularly, Malaysia is prominent owing to many Islamic finance developments at institutional levels. 
All index price is expressed in US\$ for homogeneity. The indexes data is downloaded from DataStream, while estimates of the Association of Religion Data Archives (ARDA) have been used to classify population on the basis of religious beliefs (Table 1). Indonesia and Pakistan are classified as having primary religion as Islam on the basis of criteria set by Lucey and Zhang (2010), which articulates that if eighty percent or more population is adherent to a particular religion, then it can be said to be its primary religion.

TABLE 1

Classification of Population on the Basis of Religion

\begin{tabular}{lll}
\hline \hline Country & Muslims (\% population) & Non-Muslims (\% population) \\
\hline China & 1.16 & 98.40 \\
India & 14.16 & 85.84 \\
Indonesia & 79.14 & 20.86 \\
Malaysia & 56.5 & 43.50 \\
Pakistan & 96.2 & 3.80 \\
\hline \hline
\end{tabular}

Source: The Association of Religion Data Archives

(http://www.thearda.com/internationalData/countries)

\section{MSCI Islamic Index Methodology}

The methodology for the formation of Islamic Index of Morgan Stanley Capital International (MSCI) is approved by the members of its Shar'̄'ah advisors' committee. MSCI uses two kinds of measures for screening securities i.e., business activity and financial ratios. Companies whose adequate financial information is not available regarding business activities, are taken as non-compliant with the MSCI's Islamic Index criteria. Shari'‘ ah principles restrict the investment in firms which are involved in, or earn more than 5\% of their revenue from interest based businesses (conventional banks), liquor, tobacco, pork and allied products, weapons, gambling \& casinos, music, hotels, cinema and pornography. As regard the second selection process, investment is not allowed in businesses earning substantial income from rib $\bar{a}$ or firms having disproportionate leverage. Three types of accounting ratios are used by MSCI for the testing the compliance of the business firms with Sharī'ah, namely, (i) total debt to total assets, (ii)Sum of cash and interest-bearing securities to total assets, (iii) Sum of accounts receivables and cash to total assets. Out of above three, none can exceed $33.33 \%$ for stocks to remain within the ambit of Shari' ah compliant status. For any company to be entered in the MSCI, it uses the above stated criteria with upper threshold of $30 \%$ - if the ratios exceed 30\% the stock is not included in Islamic index. In case a firm gets a portion of its profits from rib $\bar{a}$ or prohibited activities, a purification process is applied in the form of dividend adjustment factor. Ideally, this portion has to be subtracted from the dividend disbursed to stockholders; and is paid to charity.

\section{Methodology for Spillover Measurement}

The return and volatility spillovers are measured in this study using the spillover index approach introduced by Diebold and Yilmaz (2012), hereafter referred as DY2012, built on the idea of Forecast Error Variance (FEV) decomposition in the generalized VAR framework of Koop, Pesaran, and Potter (1996) and Pesaran and Shin (1998a, 1998b). It has the advan- 
tage of removing any potential dependency of the variance decomposition results on the ordering of the variables. This methodology has been used to identify the part of the FEV of a variable $i$ which can be endorsed to shocks in another variable $j \neq i$ and accumulate these measures for making spillover indexes. Moreover, with rolling window estimation, it captures the evolution of the degree and direction of spillover effects over time. This way, it can be determined whether a specific variable is a net sender or recipient of spillovers during a particular time frame. This method identifies the portion of the FEVs of any stock index $\mathrm{i}$ which can be assigned to shocks in another stock index $\mathrm{j}$ for all $i \neq j$. Next, addition of all $i=1,2, \ldots, N$ will be done to get a sole spillover index, which is summation of all non-diagonal components of FEV-covariance matrix. The starting point of the examination is the undermentioned covariance stationary $N$-variable $\operatorname{VAR}(p)$ specification:

$$
y_{t}=\sum_{i=1}^{n} \phi y_{t-i}+\varepsilon t
$$

In above equation $y_{t}$ is a vector of endogenous variables and represents either a vector of stock returns or volatility relying upon whether return or volatility transmissions are being scrutinized, $\phi$ is a $N \times N$ parameter matrix, and $\varepsilon_{t}$ is vector of error terms having zero mean. This has a moving average representation:

$$
y_{t}=\theta(L) \varepsilon_{t}
$$

Pursuing Diebold and Yilmaz (2012), own variance is specified as that proportion of $\mathrm{H}$ step-ahead error variances in forecasting $y_{i}$ due to shocks to $y_{i}$, for $i=1,2, N$, and cross variance share (spillovers) as the proportion of $\mathrm{H}$-step-ahead error variances in forecasting $y_{i}$ due to shocks to $y_{j}$, for $i \neq j$. By applying the generalized framework of Koop et al. (1996) and Pesaran and Shin (1998a, 1998b), the H-step-ahead error variance decomposition $\left[\theta_{i j}^{g}(H)\right]$ is not effected by the ordering of the variables and is defined as:

$$
\theta_{i j}^{g}(H)=\frac{\sigma_{j j}^{-1} \sum_{h=0}^{H-1}\left(e_{i}^{\prime} A_{h} \sum e_{j}\right)^{2}}{\sum_{h=0}^{H-1}\left(e_{i}^{\prime} A_{h} \sum A_{h}^{\prime} e_{i}\right)}
$$

where $\sum$ is the variance-covariance matrix of the idiosyncratic error, $\sigma_{j j}$ is the standard deviation of the idiosyncratic error for the $j$ th equation, $e_{i}$ is a selection vector with one as the ith element and zero elsewhere and $A_{h}$ is a $N \times N$ matrix of coefficient estimates. Therefore, $\theta_{i j}^{g}(H)=\left[\theta_{i j}^{g}(H)\right]_{i, j=1,2, \ldots N}$, is a $N \times N$ matrix where each element shows the influence of variable $j$ to the FEV of variable $i$. As the sum of variance contributions don not result in one in generalized decomposition, $\theta_{i j}(H)$ is regularized by the row sum yielding $\tilde{\theta}_{i j}(H)$.

Therefore, the total spillover index can be calculated as:

$$
S^{g}(H)=\frac{\sum_{i, j=1, i \neq j}^{N} \tilde{\theta}_{i j}(H)}{\sum_{i, j=1}^{N} \tilde{\theta}^{g}{ }_{i j}(H)} \times 100
$$


which provides the proportion of total FEV of common shocks, or in other words, shocks to all variables. This method also permits for the computation of the direction of the spillover, i.e., from variable $i$ TO and FROM all other variables $j$. In equation form, for spillover TO $i$ FROM $j$ is written as;

$$
S_{i \leftarrow j}(H)=\frac{\sum_{j=1, j \neq i}^{N} \tilde{\theta}^{g}{ }_{i j}(H)}{\sum_{i, j=1}^{N} \tilde{\theta}^{g}{ }_{i j}(H)} \times 100
$$

And for spillover FROM $i$ TO $j$ as;

$$
S_{i \rightarrow j}(H)=\frac{\sum_{j=1, j \neq i}^{N} \tilde{\theta}^{g}{ }_{i j}(H)}{\sum_{i, j=1}^{N} \tilde{\theta}^{g}{ }_{i j}(H)} \times 100
$$

The net spillover index is then the difference of equation 5 and 6 above, telling as to which variable is net transmitter or receiver of innovations or shocks;

$$
S_{i}^{g}(H)=S_{i \rightarrow j}(H)-S_{i \leftarrow j}(H)
$$

For net pairwise volatility spillovers, the equation can be written as:

$$
S_{i j}^{g}(H)=\left(\frac{\tilde{\theta}_{j i}(H)}{\sum_{i, k=1}^{N} \tilde{\theta}^{g}{ }_{i k}(H)}-\frac{\tilde{\theta}^{g}{ }_{j i}(H)}{\sum_{i, j=1}^{N} \tilde{\theta}^{g}{ }_{i j}(H)}\right) \times 100
$$

The net pairwise volatility spillover between markets $i$ and $j$ is simply the difference between the gross volatility shocks transmitted from market $i$ to market $j$ and those transmitted from $j$ to $i$.

\section{RESULTS AND DISCUSSION}

\section{Summary Statistics}

The statistical behavior of full sample containing all indexes return series consisting of Mean, Standard Deviation, Kurtosis, Skewness, and Jarqure-Bera are presented in Table 2, whereas the same statistics are reported for GFC period, ranging from August-2007 to June-2009 (as identified by National Bureau of Economic Research, USA), in Table $3^{3}$. 
TABLE 2

\section{Descriptive Statistics (Full Sample)-Daily Returns of Islamic and Conventional Indexes}

\begin{tabular}{|c|c|c|c|c|c|c|c|c|c|c|}
\hline & $\begin{array}{l}\text { China- } \\
\text { Conv. }\end{array}$ & $\begin{array}{l}\text { China- } \\
\text { Islamic }\end{array}$ & $\begin{array}{l}\text { India } \\
\text { Conv. }\end{array}$ & $\begin{array}{l}\text { India- } \\
\text { Islamic }\end{array}$ & $\begin{array}{l}\text { Indonesia- } \\
\text { Conv. }\end{array}$ & $\begin{array}{l}\text { Indonesia- } \\
\text { Islamic }\end{array}$ & $\begin{array}{l}\text { Malaysia- } \\
\text { Conv. }\end{array}$ & $\begin{array}{l}\text { Malaysia- } \\
\text { Islamic }\end{array}$ & $\begin{array}{l}\text { Pakistan- } \\
\text { Conv. }\end{array}$ & $\begin{array}{l}\text { Pakistan- } \\
\text { Islamic }\end{array}$ \\
\hline Mean & 0.000396 & 0.000350 & 0.000484 & 0.000454 & 0.000461 & 0.000401 & 0.000173 & 0.000248 & 0.000289 & 0.000265 \\
\hline Median & 0.000144 & 0.000148 & 0.000270 & $3.34 \mathrm{E}-05$ & 0.000492 & 0.000326 & 0.000000 & 0.000000 & $4.33 \mathrm{E}-05$ & 0.000000 \\
\hline Maximum & 0.140440 & 0.145427 & 0.150420 & 0.163086 & 0.194864 & 0.197308 & 0.057838 & 0.058409 & 0.086292 & 0.088305 \\
\hline Minimum & -0.128357 & -0.123735 & -0.199469 & -0.236690 & -0.120413 & -0.134620 & -0.112789 & -0.109984 & -0.128584 & -0.108964 \\
\hline Std. Dev. & 0.016740 & 0.017500 & 0.018323 & 0.020521 & 0.016270 & 0.016401 & 0.009505 & 0.009844 & 0.015060 & 0.016891 \\
\hline Skewness & -0.051975 & -0.007226 & -0.563130 & -0.505018 & -0.075716 & -0.158872 & -0.381494 & -0.367586 & -0.434400 & -0.246446 \\
\hline Kurtosis & 10.21168 & 9.184610 & 12.39708 & 12.44333 & 12.93825 & 13.39551 & 11.25075 & 10.47878 & 7.174172 & 6.198670 \\
\hline Jarque-Bera & 8669.845 & 6374.935 & 14928.93 & 15032.78 & 16465.29 & 18027.92 & 11442.84 & 9412.112 & 3029.754 & 1745.739 \\
\hline Probability & 0.000000 & 0.000000 & 0.000000 & 0.000000 & 0.000000 & 0.000000 & 0.000000 & 0.000000 & 0.000000 & 0.000000 \\
\hline Observations & 4000 & 4000 & 4000 & 4000 & 4000 & 4000 & 4000 & 4000 & 4000 & 4000 \\
\hline
\end{tabular}

Table 2 shows that all return series have means and medians close to zero. However, in all return series, conventional Indexes have performed better than Islamic Indexes, except in Malaysia where, mean of Islamic Index returns (.000248) is slightly better than the conventional index (.000173). The standard deviation of all Islamic indexes has slightly larger values than conventional indexes which proves more variability of return in Islamic stock markets. All return series are negatively skewed, which shows tendency of extreme negative values. Returns series of both Islamic and conventional indexes are leptokurtic which shows spikiness of data. The Jarque-Bera test shows the statistical test for normality of the data.

Descriptive statistics presented in Table 3 show that in the countries where Muslims are in majority (Indonesia and Pakistan) and including Malaysia, the Islamic Indexes outperformed their conventional counterparts, thus partly support the decoupling hypothesis. As expected, during this turbulent period, Standard deviation of Indonesia's and Pakistan's Islamic Indexes (Indonesia $=.02900$, Pakistan $=.023146$ ) are also lower than conventional Indexes (Indonesia $=.02965$, Pakistan=.023165). Moreover, during the same period, Islamic indexes of Indonesia and Pakistan (-.000427 \& -.00193) have better mean returns than their conventional counterparts (i.e., -.000518 \& -.002205). Somewhat similar trend of better performance of Islamic index (-.000517) from conventional index (-.000625) is also visible in Malaysia, but here Standard Deviation of Islamic index (.016522) is more than conventional index (.015345). However, during the same crises period, the countries where nonMuslims are in majority (China and India), the contagion occurred, and Islamic Indexes (i.e., China $=-.000545 \&$ India $=-.000866)$ were beaten by conventional Indexes (China $=-.000541$ $\&$ India $=-.000550)$.

TABLE 3

Descriptive Statistics-Daily Return of Islamic and Conventional Indexes during Crises Period: 01-08-2007 to 30-06-2009

\begin{tabular}{|c|c|c|c|c|c|c|c|c|c|c|}
\hline & $\begin{array}{l}\text { China- } \\
\text { Conv. }\end{array}$ & $\begin{array}{l}\text { China- } \\
\text { Islamic }\end{array}$ & $\begin{array}{l}\text { India- } \\
\text { Conv. }\end{array}$ & $\begin{array}{l}\text { India- } \\
\text { Islamic }\end{array}$ & $\begin{array}{l}\text { Indonesia- } \\
\text { Conv. }\end{array}$ & $\begin{array}{l}\text { Indonesia- } \\
\text { Islamic }\end{array}$ & $\begin{array}{l}\text { Malaysia- } \\
\text { Conv. }\end{array}$ & $\begin{array}{l}\text { Malaysia- } \\
\text { Islamic }\end{array}$ & $\begin{array}{l}\text { Pakistan- } \\
\text { Conv. }\end{array}$ & $\begin{array}{l}\text { Pakistan- } \\
\text { Islamic }\end{array}$ \\
\hline Mean & -0.000541 & -0.000545 & -0.000550 & -0.000866 & -0.000518 & -0.000427 & -0.000625 & -0.000517 & -0.002205 & -0.001931 \\
\hline Median & 6.40E-05 & $3.81 \mathrm{E}-05$ & 0.000000 & 0.000000 & 0.000000 & 0.000000 & 0.000000 & 0.000000 & -0.000101 & -0.000225 \\
\hline Maximum & 0.140440 & 0.145427 & 0.150420 & 0.163086 & 0.194864 & 0.197308 & 0.055464 & 0.058409 & 0.086292 & 0.088305 \\
\hline Minimum & -0.128357 & -0.123735 & -0.145755 & -0.166258 & -0.120413 & -0.130990 & -0.112789 & -0.109984 & -0.128584 & -0.108964 \\
\hline Std. Dev. & 0.031824 & 0.032366 & 0.029092 & 0.031481 & 0.029650 & 0.029000 & 0.015345 & 0.016522 & 0.023165 & 0.023146 \\
\hline Skewness & 0.116635 & 0.146890 & -0.121266 & -0.139648 & 0.336973 & 0.294996 & -0.617648 & -0.570017 & -0.435740 & -0.301285 \\
\hline Kurtosis & 5.328670 & 5.155186 & 7.189417 & 6.935305 & 7.475660 & 8.390990 & 9.286415 & 7.893281 & 5.259116 & 4.858527 \\
\hline Probability & 0.000000 & 0.000000 & 0.000000 & 0.000000 & 0.000000 & 0.000000 & 0.000000 & 0.000000 & 0.000000 & 0.000000 \\
\hline Obs. & 478 & 478 & 478 & 478 & 478 & 478 & 478 & 478 & 478 & 478 \\
\hline
\end{tabular}


Table 4 reports the descriptive stats for daily volatility of Islamic and conventional indexes of China, India, Indonesia, Malaysia and Pakistan. It can be observed that overall figures of volatility along with Standard Deviation of Islamic Indexes are larger than conventional Indexes. All series are positively skewed and have leptokurtic behavior.

TABLE 4

\section{Descriptive Statistics-Daily Volatility of Islamic and Conventional Indexes}

\begin{tabular}{lllllllllll}
\hline \hline & $\begin{array}{l}\text { China- } \\
\text { Conv. }\end{array}$ & $\begin{array}{l}\text { China- } \\
\text { Islamic }\end{array}$ & $\begin{array}{l}\text { India- } \\
\text { Conv. }\end{array}$ & $\begin{array}{l}\text { India- } \\
\text { Islamic }\end{array}$ & $\begin{array}{l}\text { Indonesia- } \\
\text { Conv. }\end{array}$ & $\begin{array}{l}\text { Indonesia- } \\
\text { Islamic }\end{array}$ & $\begin{array}{l}\text { Malaysia- } \\
\text { Conv. }\end{array}$ & $\begin{array}{l}\text { Malaysia- } \\
\text { Islamic }\end{array}$ & $\begin{array}{l}\text { Pakistan- } \\
\text { Conv. }\end{array}$ & $\begin{array}{l}\text { Pakistan- } \\
\text { Islamic }\end{array}$ \\
\hline Mean & 0.194717 & 0.206475 & 0.210545 & 0.240661 & 0.185588 & 0.189551 & 0.109989 & 0.114846 & 0.167618 & 0.192976 \\
Median & 0.162059 & 0.173586 & 0.177396 & 0.203380 & 0.150929 & 0.156253 & 0.092714 & 0.097743 & 0.134262 & 0.156108 \\
Maximum & 1.653193 & 1.614086 & 1.484759 & 1.831534 & 1.276235 & 1.314109 & 0.860453 & 0.841594 & 0.964325 & 0.982640 \\
Minimum & 0.011608 & 0.012820 & 0.000000 & 0.000000 & 0.022061 & 0.019913 & 0.004351 & 0.005948 & 0.002777 & 0.002804 \\
Std. Dev. & 0.135336 & 0.137531 & 0.144021 & 0.163073 & 0.132149 & 0.131261 & 0.071689 & 0.073475 & 0.119733 & 0.133919 \\
Skewness & 3.178243 & 2.902881 & 2.506695 & 2.370596 & 2.708798 & 2.878009 & 2.650558 & 2.402697 & 1.855463 & 1.552407 \\
Kurtosis & 20.88348 & 18.05125 & 14.31146 & 14.59792 & 15.13094 & 17.25720 & 17.86516 & 15.35710 & 7.825428 & 6.044157 \\
Jarque-Bera & 59977.24 & 43331.11 & 25488.34 & 26138.94 & 29388.91 & 39360.52 & 41470.95 & 29269.00 & 6169.778 & 3147.976 \\
Probability & 0.000000 & 0.000000 & 0.000000 & 0.000000 & 0.000000 & 0.000000 & 0.000000 & 0.000000 & 0.000000 & 0.000000 \\
Obs. & 3996 & 3996 & 3996 & 3996 & 3996 & 3996 & 3996 & 3996 & 3996 & 3996 \\
\hline \hline
\end{tabular}

\section{RESULTS AND DISCUSSION}

Returns have been computed by taking the log price daily $\left\{\right.$ daily index return $\left.=\ln \left(P_{t} / P_{t-1}\right)\right\}$, where, $\ln$ is natural logarithm, $P_{t}$ is current day index price and $P_{t-1}$ is previous day index price. Taking natural logarithm has advantage of data smoothing and linearization. Volatility is measured by the annualized standard deviation of past daily stock price movements. The necessary condition of data stationarity has been checked using Augmented Dickey Fuller (ADF) unit root test, which reflected that all data series are stationary at level I (0). By means of the DY2012, a rolling window method has been used, owing to its simplicity and effectiveness, in approximating the presence of time dependent spillovers of financial data. This study used 200-day rolling sample windows and a forecast horizon $(\mathrm{H})$ of 10 days for estimating the spillover indexes. For each window, selection of the lag length specification $(p)$ of the VAR model is done by the Akaike Information Criterion (AIC).

The Return and Volatility Spillover indexes are reported in Table 5 and Table 6, respectively. It can be seen from Table 5 that in all five countries, there is huge return spillover between Islamic and conventional indexes which ranges from 27.7 to 54.2. China Islamic Index (CII) emerged as most influential (77.3) in transmitting the return shocks to other indexes, followed by China Conventional Index (CCI) and India Conventional Index (INCI) with score (76.4) and (71.5), respectively. $\mathrm{CCI}$ and $\mathrm{CII}$ are on average contributing 6\% to 7\% to each indexes of India, Indonesia and Malaysia. However, China's indexes (Islamic and conventional) have negligible impact on Pakistan's Islamic and conventional indexes. Effect of return shocks among Islamic and conventional indexes of India, Indonesia, Malaysia ranges from $4 \%$ to $8 \%$. Interestingly, however, Pakistan is again least affected from other three countries in the sample.

By seeing the contribution "From" others, it is revealed that China's indexes $(70.6$ \& 70.9) are the highest receiver of return shocks, as were the highest in initiators category 
stated above, followed by close margin by India ( $67.6 \& 66.0)$, Indonesia ( $68.2 \& 64.4)$ and Malaysia (68.6 \& 66.7). It can also be noted that in the whole sample set of ten indexes, return shocks of Islamic indexes are slightly less than conventional indexes. Moreover, Pakistan's Islamic and conventional indexes score of 46.4 and 45.8 respectively is far less than the average score of other four countries, in the context of contribution "From" others category. The overall Return Spillover Index is $63.52 \%$ which shows interconnectedness among the sample countries.

The volatility spillover of Islamic and conventional indexes of China, India, Indonesia, Malaysia and Pakistan are reported in Table 6. The intra-country volatility spillovers between Islamic and conventional indexes are within the range of 28.80 to 61.46. One striking feature of this table is that the total volatility spillover is $52.9 \%$ which is less than the total returns spillover of $63.52 \%$, as presented in Table 5. Generally, in stock market, total volatility spillover is expected to be more than total returns spillover; for example, results reported by Diebold and Yilmaz (2008) for return and volatility spillover were 35.5\% and $39.5 \%$ respectively. Similar results are also presented by Li and Giles (2015) in their study.

Conventional indexes of China (7.51) and India (9.85), where non-Muslims are in majority, emerged as major net contributor of volatility shocks. However, their spillover to Muslim majority countries (Indonesia and Pakistan) is less than the volatility spillover between them (China-India) and to Malaysia. This lesser value of interrelationship between Islamic and conventional indexes of Muslim countries indicates their little exposure to volatility risk from other countries' emerging markets of Asia. This low connectedness was also reported in the study of Al-Khazali, Lean, and Samet (2014); El Mehdi and Mghaieth (2017); and Walkshäusl and Lobe (2012). Overall, Islamic indexes are net receiver of spillover by a meager percentage. Once again, Pakistan is least effected by volatility spillover of other four countries in the sample.

\section{Dynamic Analysis}

In the second strand of analysis, dynamic analysis has been conducted in which return and volatility spillover plots are produced using 200 week rolling windows, so that the average behavior of the sample statistics presented in Tables 2, 3 and 4 may not undermine the cyclical movements during the whole sample period. As a first step, total return and volatility spillover plots are drawn. Figure 2 shows the total return spillover index across Islamic and conventional indexes of five selected emerging Asian stock markets. Whole sample depicts spillover effects in returns having substantial values, and signals the presence of connections between Islamic and conventional indexes. However, as already described in the explanation of Table 3, a downward slope can be seen in the returns spillover during GFC of 2008.

Figure 3 represents the total volatility spillover index plot for the whole sample, for Islamic and conventional indexes. It can be observed, generally an increasing trend of spillover in both return and volatility plots, after the GFC of 2008, which stays till mid of 2010. Again a sharp upward trend is noticed in 2011-12 when European sovereign debt crisis erupted. In mid-2015, due to Chinese Stock market crises, volatility spillover increased from 55 to 65 and the upward trend continued to the level of 75 in the first quarter 
of 2016. After that we see gradual decrease in volatility spillover that reduced to the level of 55 in 2017.

TABLE 5

Return Spillovers: Islamic and Conventional Indexes

\begin{tabular}{llllllllllll}
\hline \hline & CCI & CII & INCI & INII & IDCI & IDII & MCI & MII & PCI & PII & $\begin{array}{l}\text { Contribution } \\
\text { from others }\end{array}$ \\
\hline CCI & 29.30 & 27.90 & 8.30 & 7.30 & 7.30 & 5.60 & 7.60 & 6.30 & 0.20 & 0.10 & 70.60 \\
CII & 27.70 & 29.10 & 8.10 & 7.20 & 7.40 & 5.60 & 7.90 & 6.60 & 0.20 & 0.20 & 70.90 \\
INCI & 8.70 & 8.50 & 32.60 & 29.60 & 5.70 & 4.30 & 5.60 & 4.50 & 0.40 & 0.30 & 67.60 \\
INII & 7.90 & 7.90 & 30.80 & 33.90 & 5.40 & 4.10 & 5.10 & 4.10 & 0.40 & 0.30 & 66.00 \\
IDCI & 8.10 & 8.20 & 6.10 & 5.50 & 31.80 & 26.80 & 7.10 & 6.00 & 0.20 & 0.20 & 68.20 \\
IDII & 6.90 & 7.00 & 4.90 & 4.50 & 30.00 & 35.50 & 5.90 & 4.90 & 0.10 & 0.20 & 64.40 \\
MCI & 8.40 & 8.80 & 6.10 & 5.30 & 7.60 & 5.70 & 31.30 & 26.00 & 0.40 & 0.30 & 68.60 \\
MII & 7.70 & 8.00 & 5.40 & 4.80 & 7.00 & 5.30 & 28.00 & 33.40 & 0.30 & 0.20 & 66.70 \\
PCI & 0.60 & 0.60 & 1.00 & 0.90 & 0.50 & 0.40 & 0.90 & 0.40 & 53.60 & 41.10 & 46.40 \\
PII & 0.40 & 0.40 & 0.80 & 0.60 & 0.50 & 0.40 & 0.60 & 0.40 & 41.70 & 54.20 & 45.80 \\
Contribution & 76.40 & 77.30 & 71.50 & 65.70 & 71.40 & 58.20 & 68.70 & 59.20 & 43.90 & 42.90 & 635.20 \\
to others & & & & & & & & & & & \\
Contribution & 105.70 & 106.40 & 104.10 & 99.60 & 103.20 & 93.70 & 100.00 & 92.60 & 97.50 & 97.10 & Spillover \\
including & & & & & & & & & & & Index = \\
own & & & & & & & & & & & $63.52 \%$ \\
\hline
\end{tabular}

Mnemonics: China Conventional Index=CCI, China Islamic Index=CII, India Conventional Index=INCI, India Islamic Index=INII, Indonesia Conventional Index=IDCI, Indonesia Islamic Index=IDII, Malaysia Conventional Index $=$ MCI, Malaysia Islamic Index $=$ MII, Pakistan Conventional Index =PCI, Pakistan Islamic Index $=$ PII

TABLE 6

Volatility Spillovers: Islamic and Conventional Indexes

\begin{tabular}{lllllllllllll}
\hline \hline & CCI & CII & INCI & INII & IDCI & IDII & MCI & MII & PCI & PII & $\begin{array}{l}\text { Contribution } \\
\text { from others }\end{array}$ & Net Spillover \\
\hline CCI & 39.74 & 31.33 & 6.56 & 5.53 & 3.84 & 3.68 & 4.80 & 4.43 & 0.05 & 0.04 & 60.26 & 7.51 \\
CII & 34.13 & 37.75 & 5.83 & 4.91 & 3.69 & 3.63 & 5.47 & 4.53 & 0.04 & 0.03 & 62.26 & -2.65 \\
INCI & 6.12 & 5.01 & 44.96 & 32.09 & 2.90 & 2.30 & 3.26 & 2.80 & 0.41 & 0.14 & 55.03 & 9.85 \\
INII & 6.23 & 5.11 & 34.08 & 44.27 & 2.91 & 2.37 & 2.58 & 2.11 & 0.23 & 0.11 & 55.73 & 0.23 \\
IDCI & 5.34 & 4.14 & 4.82 & 3.76 & 43.19 & 30.05 & 4.06 & 4.24 & 0.37 & 0.04 & 56.82 & -4.11 \\
IDII & 4.56 & 3.47 & 3.59 & 3.00 & 30.99 & 47.28 & 2.73 & 3.44 & 0.70 & 0.24 & 52.72 & -2.83 \\
MCI & 5.62 & 5.44 & 4.49 & 3.06 & 4.33 & 3.43 & 44.67 & 28.89 & 0.04 & 0.04 & 55.34 & -3.32 \\
MII & 5.26 & 4.80 & 4.22 & 3.01 & 3.66 & 3.44 & 28.80 & 46.67 & 0.11 & 0.03 & 53.33 & -2.74 \\
PCI & 0.19 & 0.11 & 0.67 & 0.30 & 0.26 & 0.64 & 0.22 & 0.09 & 61.46 & 36.06 & 38.54 & 0.43 \\
PII & 0.32 & 0.20 & 0.62 & 0.30 & 0.13 & 0.35 & 0.10 & 0.06 & 37.02 & 60.88 & 39.10 & -2.37 \\
$\begin{array}{l}\text { Contribution } \\
\text { to others }\end{array}$ & 67.77 & 59.61 & 64.88 & 55.96 & 52.71 & 49.89 & 52.02 & 50.59 & 38.97 & 36.73 & 529.13 & \\
$\begin{array}{l}\text { Contribution } \\
\text { including }\end{array}$ & & & & & & & & & & & & \\
own & 97.36 & 109.84 & 100.23 & 95.90 & 97.17 & 96.69 & 97.26 & 100.43 & 97.61 & Total & \\
\hline
\end{tabular}

Mnemonics: China Conventional Index=CCI, China Islamic Index=CII, India Conventional Index=INCI, India Islamic Index=INII, Indonesia Conventional Index=IDCI, Indonesia Islamic Index=IDII, Malaysia Conventional Index $=$ MCI, Malaysia Islamic Index $=$ MII, Pakistan Conventional Index $=$ PCI, Pakistan Islamic Index $=$ PII

In the second step of the dynamic analysis, for identifying the major net transmitter and receivers of the volatility spillover, directional information is introduced in spillover plot 
and reported in Figure 4 which reflects the visual confirmation of earlier reported results of Table 5. China Islamic Index (CII) stood highest (62.26) in 'contribution from others' category, followed by China Conventional Index (60.26) and Indonesia Islamic Index (IDII) (56.82). Figure 5 reports the net volatility spillover plots of Islamic and conventional indexes of China, India, Indonesia, Malaysia and Pakistan. Overall, positive values during the whole sample period have been observed in China Conventional Index (CCI) and India Conventional Index (INCI), making them the strong transmitter of volatility shocks in the study sample. Generally, all Islamic Indexes remained the net receiver of volatility spillover with a thin negative score ranging from 2.65 to -4.11 .

Lastly in dynamic analysis, the net pairwise directional volatility spillovers have been calculated as reported in Figure 6. Total 45 pairs were formed keeping in view the ten Indexes of five selected emerging Asian countries' stock markets (18 reported). While examining the pairwise spillover plots of China's Islamic and conventional indexes, it is found that these are mainly transmitter of volatility to all other conventional and Islamic indexes of the sample, except India's Islamic and conventional indexes, from where China receives net volatility shocks. Pairwise net volatility of India's Islamic and conventional indexes reveal that these are also net transmitter of volatility to all other indexes. Indonesia's conventional index is net receiver of volatility spillover from Malaysian Islamic and Pakistan's conventional indexes. Pakistan's conventional index is also transmitter of volatility spillover to Malaysian Islamic index.

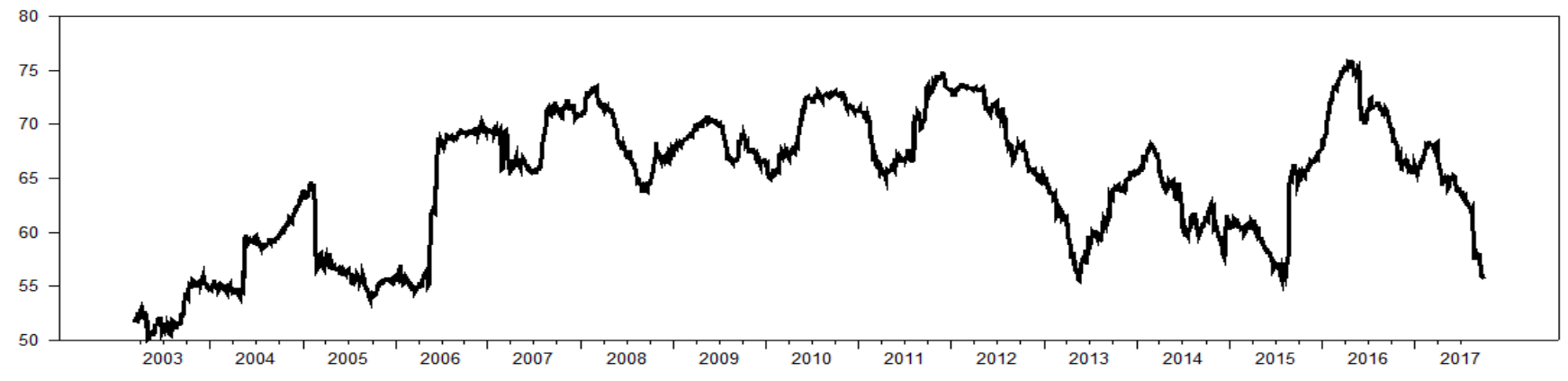

FIGURE 1. Return spillover plot, 200 week window, 10 step horizon

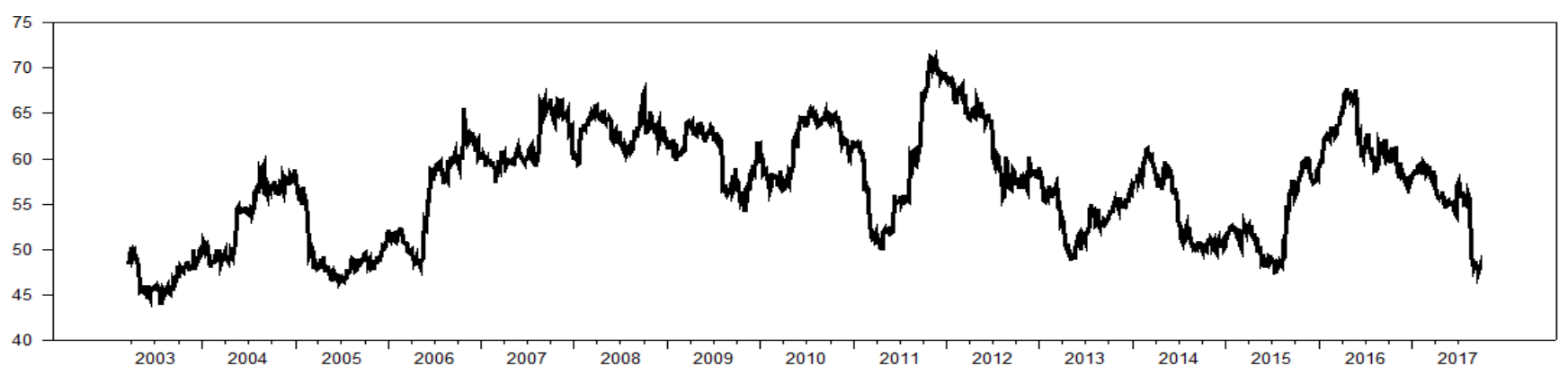

FIGURE 2. Volatility spillover plot, 200 week window, 10 step horizon 

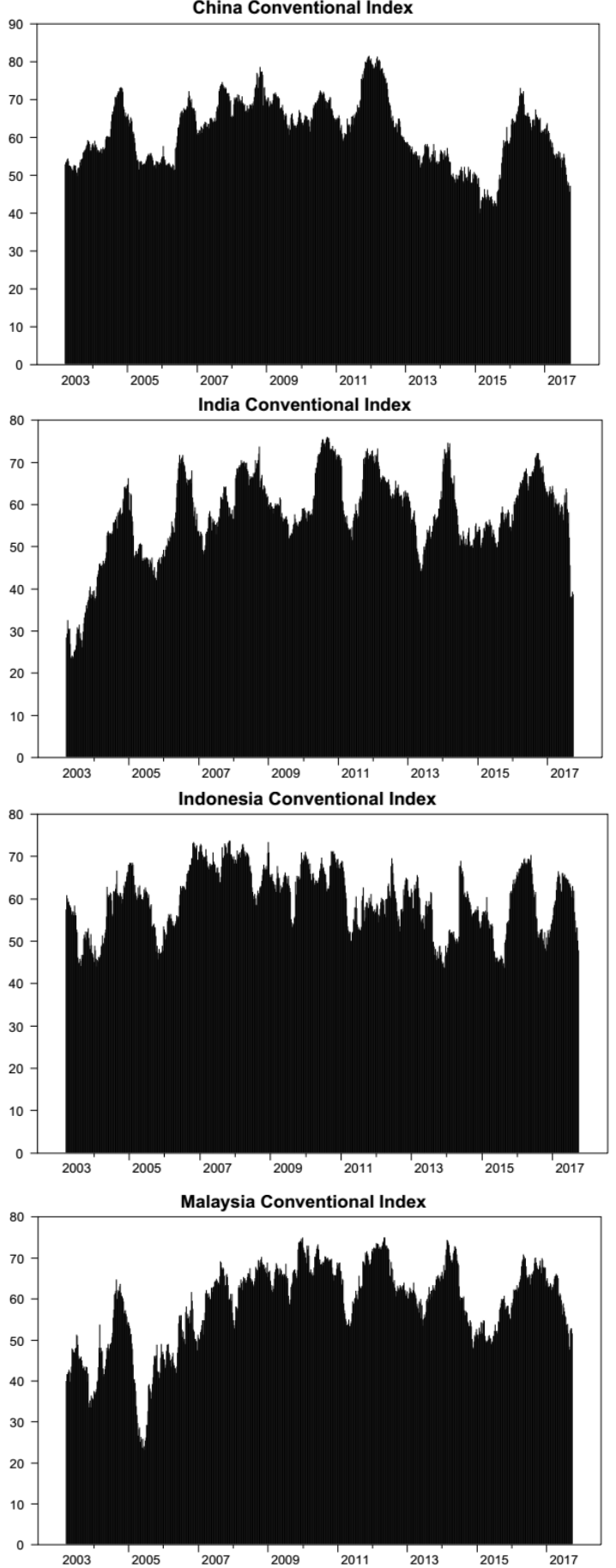

Pakistan Conventional Index

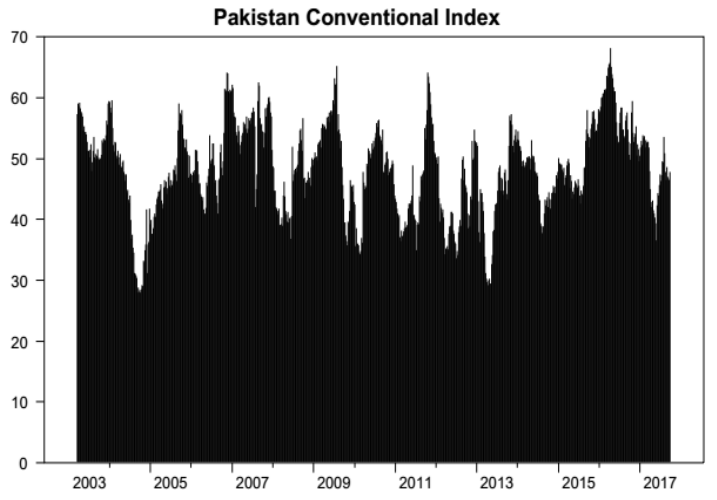

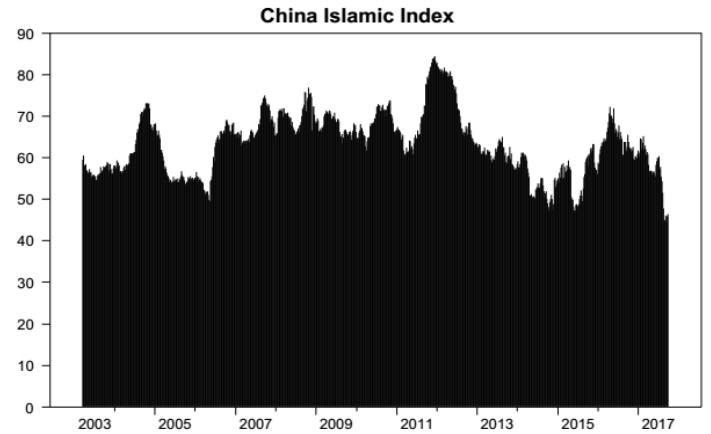
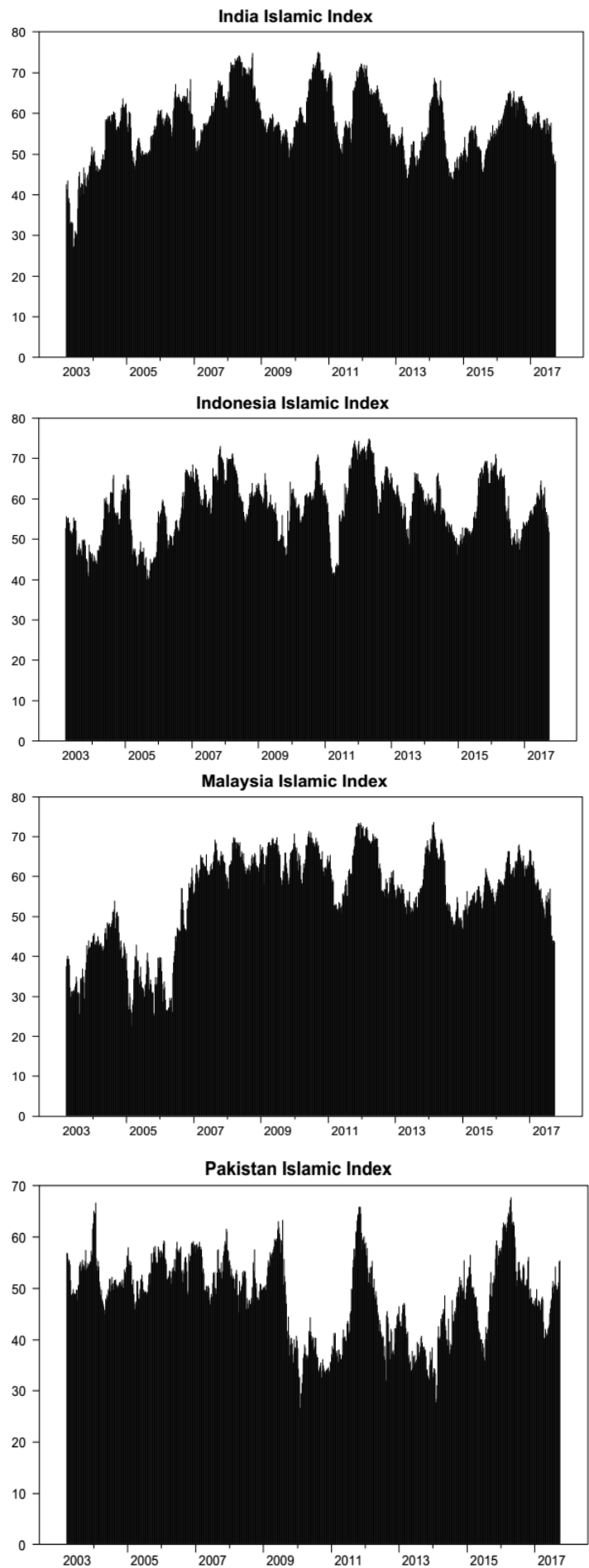

FIGURE 3. Directional volatility spillovers, from Islamic and conventional indexes 

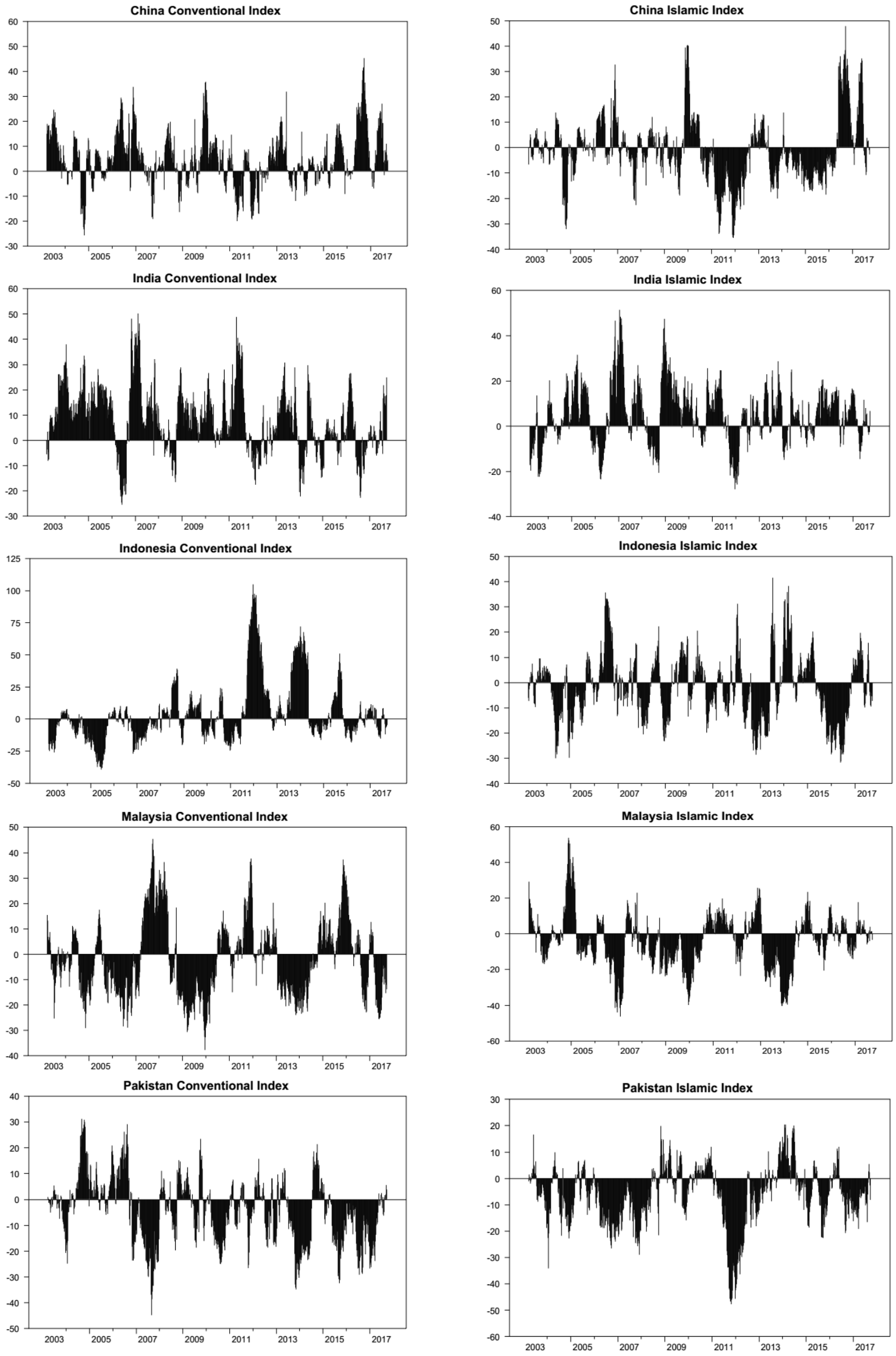

FIGURE 4. Net volatility spillovers, Islamic and conventional indexes 
China C-China

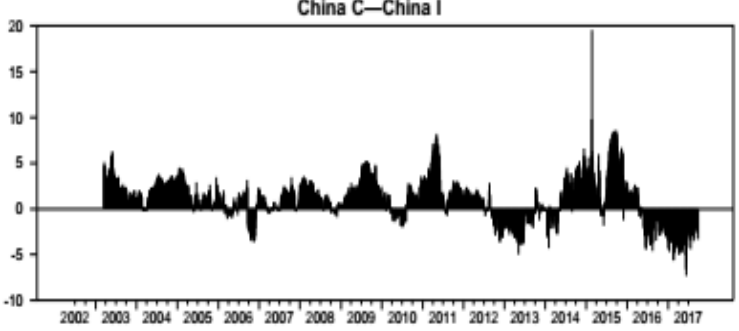

China C-India C

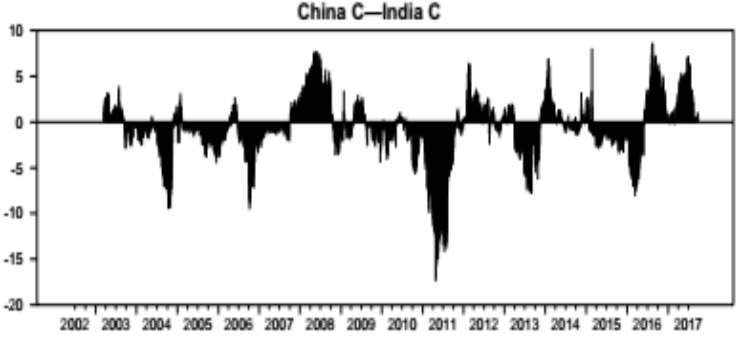

China C-India I

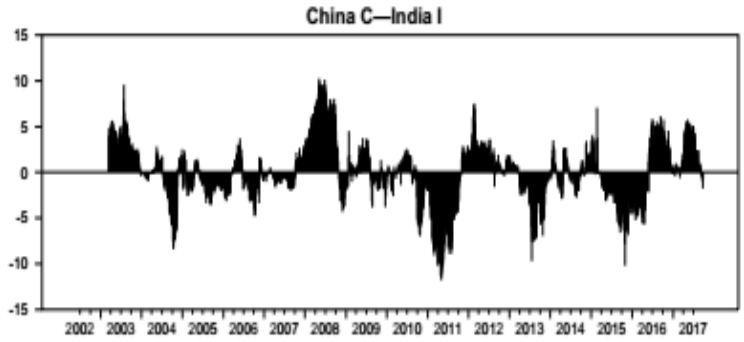

India C-Indonesia C

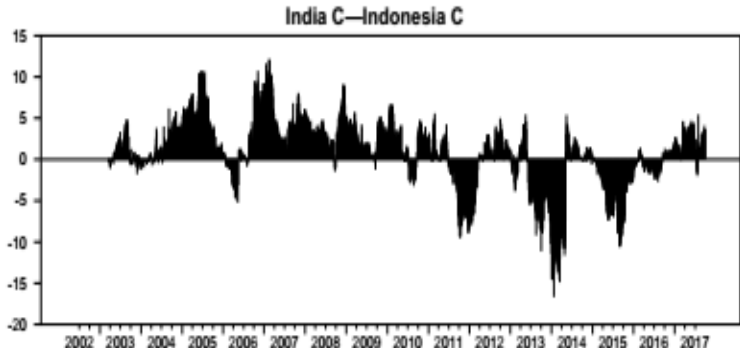

India C-Indonesia |

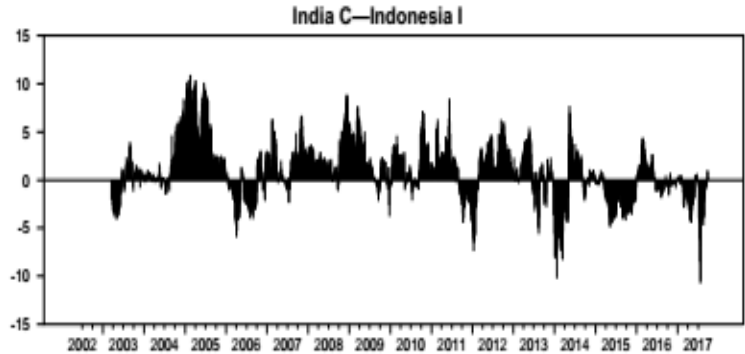

India C-Malaysia C

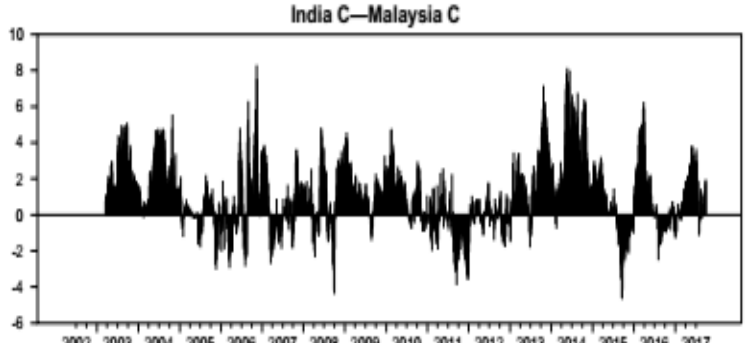

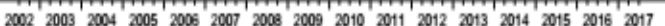
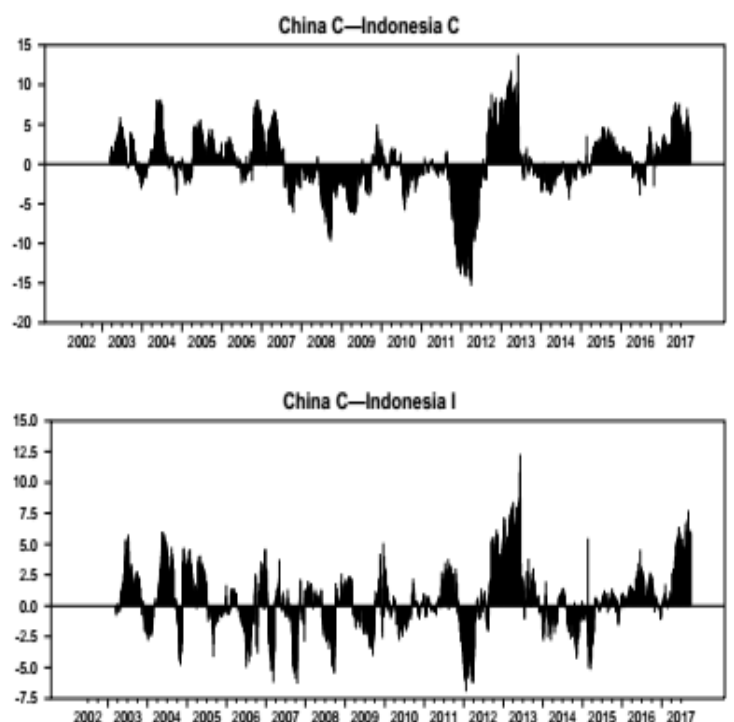

China C-Malaysia C

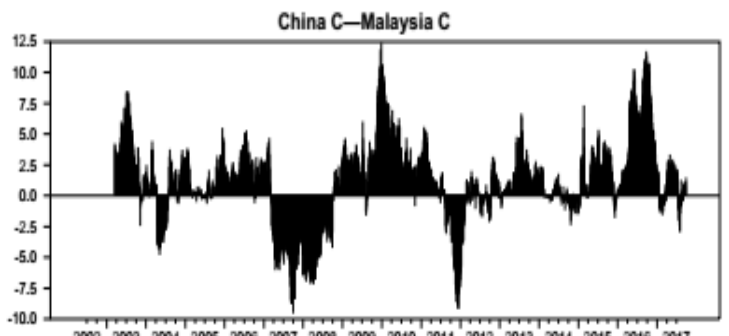

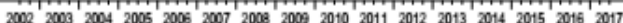

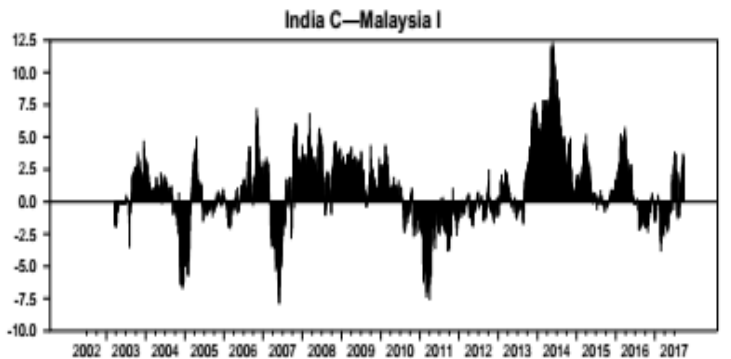

India C-Pakistan C

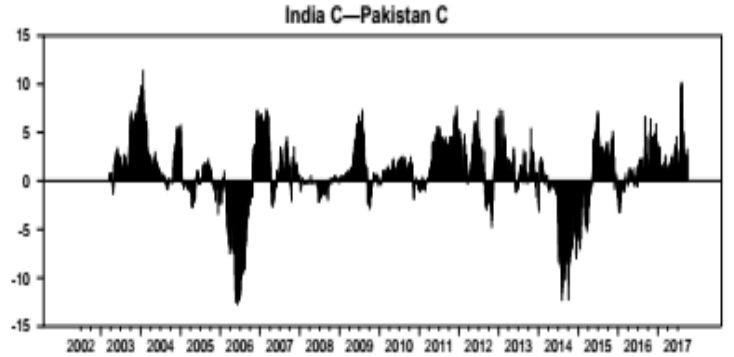

India C-Pakistan

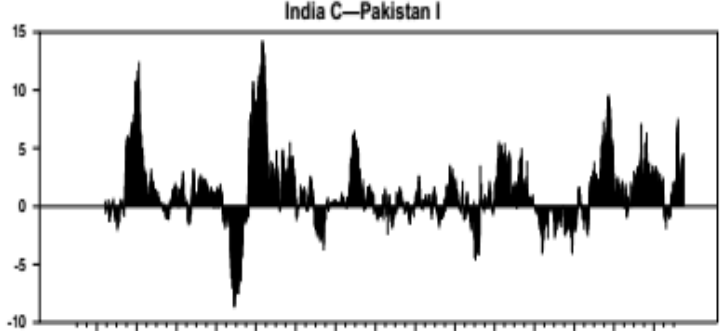

$20022003200420052005200720082009201020112012 \quad 20132014201520162017$ 

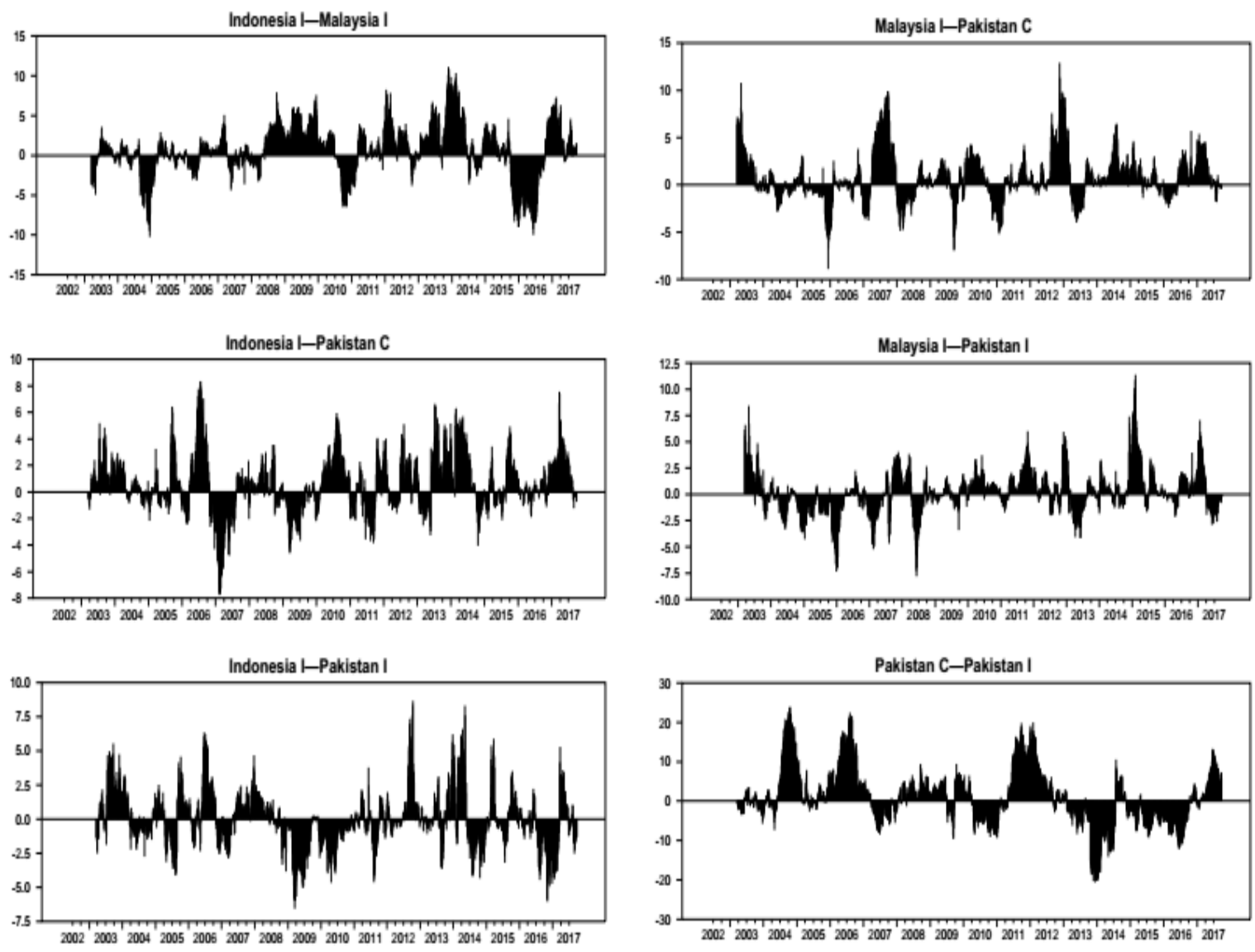

FIGURE 5. Net pairwise volatility spillovers, Islamic and conventional indexes

\section{CONCLUSION}

The chief inspiration for this study stems from the prevalent perception that the explicit Islamic investment criteria may offer Islamic indexes higher returns, growth, and provide a shield against the ever increasing risk and volatility in conventional indexes. The study uses the methodology developed by DY-2012 for finding return and volatility spillover in i) Islamic and conventional indexes and vice versa; ii) the distinct performance of Islamic Indexes from conventional counterparts during GFC-2008; and iii) impact of religious faiths on the spillovers in both type of settings i.e., major population is Muslims or not. It is not concerned with overall diversification, rather focuses on the distinctive performance of Islamic indexes from conventional, along-with religious impact on it, if any.

There are quite a few explanations why one can presume dissimilarities in the patterns of return and volatility transmission across the conventional and Islamic indexes. Firstly, because nature of business must be Sharī'ah compliant, secondly prohibition of interest $(r i b \bar{a})$ income, thirdly the lower leverage ratios, and finally, the restrictions on doing speculative (gharar based) transactions or activities without any real/constructive assets and economic benefits. The return and volatility spillovers from Islamic to conventional indexes and vice-versa, pertaining to five selected emerging Asian markets i.e., China, India, Indonesia, Malaysia, and Pakistan have been measured using the spillover index approach introduced 
by Diebold and Yilmaz (2012), built on the idea of Forecast Error Variance (FEV) decomposition in the generalized VAR framework. Secondary data from Morgan Stanley Capital International (MSCI) Islamic and conventional indexes for five selected countries and ten indexes for the period from May-2002 to September-2017 have been used.

Results show transmission of return and volatility shocks among Islamic and conventional stock markets. The net volatility spillovers analysis discloses that Islamic indexes are recipients of volatility spillovers from conventional indexes both in countries where non-Muslims are in majority (China and India) and in countries where Muslims are in majority (Indonesia and Pakistan). Such results were previously reported by Ajmi et al. (2014), Hammoudeh et al. (2014) and Rizvi et al. (2015). Moreover, during the overall sample period, mean returns of conventional indexes are better than Islamic indexes. However, during the GFC of 2008, Islamic indexes comparatively performed better than their conventional counterparts in Indonesia and Pakistan where Muslims are in majority. These findings are partly in line with the studies of Ho et al. (2014) and Miniaoui et al. (2015), thus providing a little diversification opportunity during the turbulent periods. Total return spillover score is more than total volatility spillover, which suggests that in the sample countries, shock transmission is more by real returns than mere by transmission of news. Therefore, generally, Islamic investment criteria applied in the formation of Islamic indexes do not offer any absolute cushion against return and volatility shocks that might affect the conventional indexes or large diversification benefits for hedge funds. So, during normal periods, faith-based investors and portfolio managers may not get the desired benefit of diversification linked with investing in Islamic assets alone; therefore, they should include other classes of assets in their portfolios to mitigate risk. Interestingly, Pakistan turned out to be least affected in terms of return and volatility spillover from all other four countries in the sample, but to prove whether this is due to Shari' 'ah investment criteria employed as institutional factor in the financial markets, or the behavior profoundly imbedded in the Muslims, needs more extensive research.

The findings are significant for policy makers and fund managers. As the evidence of financial interdependency specifies that the financial blows in a market will spillover to next market, therefore, to deal with such reciprocities of stock markets, policy makers may formulate such strategies which can be helpful in maintaining financial stability. Furthermore, investors may invest in those Islamic stocks which offer highest returns as compared to the conventional stocks of various markets in different countries. This study also sheds some light whether religious beliefs of a majority of population impact the return and volatility transmission or otherwise.

\section{REFERENCES}

Abbas, Q., Khan, S., \& Shah, S. Z. A. (2013). Volatility transmission in regional Asian stock markets. Emerging Markets Review, 16, 66-77. doi: https://doi.org/10.1016/j.ememar.2013.04.004

Ahmad, W., Rais, S., \& Shaik, A. R. (2018). Modelling the directional spillovers from DJIM Index to conventional benchmarks: Different this time? The Quarterly Review of Economics and Finance, 67, 14-27.doi: https://doi.org/10.1016/j.qref.2017.04.012 
Ajmi, A. N., Hammoudeh, S., Nguyen, D. K., \& Sarafrazi, S. (2014). How strong are the causal relationships between Islamic stock markets and conventional financial systems? Evidence from linear and nonlinear tests. Journal of International Financial Markets, Institutions and Money, 28, 213-227. doi: https://doi.org/10.1016/j.intfin.2013.11.004

Akhtar, M. F., Ali, K., \& Sadaqat, S. (2011). Factors influencing the profitability of Islamic banks of Pakistan. International Research Journal of Finance and Economics, 66(66), $1-8$.

Al-Khazali, O., Lean, H. H., \& Samet, A. (2014). Do Islamic stock indexes outperform conventional stock indexes? A stochastic dominance approach. Pacific-Basin Finance Journal, 28, 29-46. doi: https://doi.org/10.1016/j.pacfin.2013.09.003

Archer, S., \& Karim, R. A. A. (2007). Islamic finance: The regulatory challenge. New York, NY: John Wiley \& Sons. doi: https://doi.org/10.1002/9781118390443

Aydemir, O., \& Demirhan, E. (2009). The relationship between stock prices and exchange rates: Evidence from Turkey. International Research Journal of Finance and Economics, 23(2), 207-215.

Ayub, M. (2007). Understanding Islamic finance. London, UK: John Wiley \& Sons.

Baillie, R. T., \& DeGennaro, R. P. (1990). Stock returns and volatility. Journal of financial and Quantitative Analysis, 25(2), 203-214. doi: https://doi.org/10.2307/2330824

Balasubramanyan, L., \& Premaratne, G. (2003). Volatility spillover and co-movement: Some new evidence from Singapore (Working paper). National University of Singapore, Singapore.

Bekaert, G., \& Harvey, C. R. (1997). Emerging equity market volatility. Journal of Financial Economics, 43(1), 29-77. doi: https://doi.org/10.1016/S0304-405X(96)00889-6

Billah, M., M. (2003). Islamic and modern insurance: Principles and practices. Selangor, Malaysia: Ilmiah Publishers Sdn Bhd.

Bin Mahfouz, S., \& Ahmed, H. (2014). Shariah investment screening criteria: A critical review. Journal of King Abdulaziz University: Islamic Economics, 27(1), 111-145.

Bollerslev, T., Engle, R. F., \& Wooldridge, J. M. (1988). A capital asset pricing model with time-varying covariances. Journal of political Economy, 96(1), 116-131. doi: https://doi.org/10.1086/261527

Cheung, Y. W., \& Ng, L. K. (1993). Interactions between the US and Japan stock market indices. Journal of International Financial Markets, Institutions $\mathcal{E}$ Money, 2(2), 51-70.

Corradi, V., Distaso, W., \& Fernandes, M. (2012). International market links and volatility transmission. Journal of Econometrics, 170(1), 117-141. doi: https://doi.org/10.1016/j.jeconom.2012.03.003

Datta, D. K., Rajagopalan, N., \& Rasheed, A. M. (1991). Diversification and performance: Critical review and future directions. Journal of Management Studies, 28(5), 529-558. doi: https://doi.org/10.1111/j.1467-6486.1991.tb00767.x

Derigs, U., \& Marzban, S. (2009). New strategies and a new paradigm for Shariahcompliant portfolio optimization. Journal of Banking $\mathcal{F}$ Finance, 33(6), 1166-1176. doi: https://doi.org/10.1016/j.jbankfin.2008.12.011 
Dewandaru, G., Rizvi, S. A. R., Masih, R., Masih, M., \& Alhabshi, S. O. (2014). Stock market co-movements: Islamic versus conventional equity indices with multi-timescales analysis. Economic Systems, 38(4), 553-571. doi: https://doi.org/10.1016/j.ecosys.2014.05.003

Diebold, F. X., \& Yilmaz, K. (2008). Measuring financial asset return and volatility spillovers, with application to global equity markets. The Economic Journal, 119(534), 158-171. doi: https://doi.org/10.1111/j.1468-0297.2008.02208.x

Diebold, F. X., \& Yilmaz, K. (2012). Better to give than to receive: Predictive directional measurement of volatility spillovers. International Journal of Forecasting, 28(1), 5766. doi: https://doi.org/10.1016/j.ijforecast.2011.02.006

Dymski, G. A. (2005). Financial globalization, social exclusion and financial crisis. International Review of Applied Economics, 19(4), 439-457.

doi: https://doi.org/10.1080/02692170500213319

El Khamlichi, A., Sarkar, K., Arouri, M., \& Teulon, F. (2014). Are Islamic equity indices more efficient than their conventional counterparts? Evidence from major global index families. Journal of Applied Business Research, 30(4), 1137-1150.

doi: https://doi.org/10.19030/jabr.v30i4.8660

El Mehdi, I. K., \& Mghaieth, A. (2017). Volatility spillover and hedging strategies between Islamic and conventional stocks in the presence of asymmetry and long memory. Research in International Business and Finance, 39, 595-611. doi: https://doi.org/10.1016/j.ribaf.2016.04.006

El-Gamal, M. A. (2006). Islamic finance: Law, economics and practice. New York, NY: Cambridge University Press. doi: https://doi.org/10.1017/CBO9780511753756

Elgari, M. A. (2003). Credit risk in Islamic banking and finance. Islamic Economic Studies, $10(2), 1-25$.

Eun, C. S., \& Shim, S. (1989). International transmission of stock market movements. Journal of Financial and Quantitative Analysis, 24(2), 241-256. doi: https://doi.org/10.2307/2330774

French, K. R., Schwert, G. W., \& Stambaugh, R. F. (1987). Expected stock returns and volatility. Journal of Financial Economics, 19(1), 3-29.

doi: https://doi.org/10.1016/0304-405X(87)90026-2

Hamao, Y., Masulis, R. W., \& Ng, V. (1990). Correlations in price changes and volatility across international stock markets. The Review of Financial Studies, 3(2), 281-307. doi: https://doi.org/10.1093/rfs/3.2.281

Hammoudeh, S., Mensi, W., Reboredo, J. C., \& Nguyen, D. K. (2014). Dynamic dependence of the global Islamic equity index with global conventional equity market indices and risk factors. Pacific-Basin Finance Journal, 30, 189-206.

doi: https://doi.org/10.1016/j.pacfin.2014.10.001

Hassan, K., \& Mahlknecht, M. (2011). Islamic capital markets: Products and strategies. West Sussex, UK: John Wiley \& Sons.

Hkiri, B., Hammoudeh, S., Aloui, C., \& Yarovaya, L. (2017). Are Islamic indexes a safe haven for investors? An analysis of total, directional and net volatility spillovers be- 
tween conventional and Islamic indexes and importance of crisis periods. Pacific-Basin Finance Journal, 43, 124-150. doi: https://doi.org/10.1016/j.pacfin.2017.03.001

Ho, C. S. F., Rahman, N. A. A., Yusuf, N. H. M., \& Zamzamin, Z. (2014). Performance of global Islamic versus conventional share indices: International evidence. Pacific-Basin Finance Journal, 28, 110-121. doi: https://doi.org/10.1016/j.pacfin.2013.09.002

Indrawati, T. (2002). Dynamic relationships among variables macro-monetary and stock market indices with Granger Non-Causality (GNC) approach in VAR and VEC (Doctoral dissertation). University of Indonesia, Depok, Indonesia.

Iqbal, Z., \& Mirakhor, A. (2011). An introduction to Islamic finance: Theory and practice. New York, NY: John Wiley \& Sons. doi: https://doi.org/10.1002/9781118390474

Jebran, K., Chen, S., \& Tauni, M. Z. (2017). Islamic and conventional equity index comovement and volatility transmission: Evidence from Pakistan. Future Business Journal, 3(2), 98-106. doi: https://doi.org/10.1016/j.fbj.2017.05.001

Kim, S. W., \& Rogers, J. H. (1995). International stock price spillovers and market liberalization: Evidence from Korea, Japan, and the United States. Journal of Empirical Finance, 2(2), 117-133. doi: https://doi.org/10.1016/0927-5398(94)00013-7

King, M. A., \& Wadhwani, S. (1990). Transmission of volatility between stock markets. The Review of Financial Studies, 3(1), 5-33. doi: https://doi.org/10.1093/rfs/3.1.5

King, M., Sentana, E., \& Wadhwani, S. (1990). Volatiltiy and links between national stock markets. Econometrica, 62(4), 901-933. doi: https://doi.org/10.2307/2951737

Koop, G., Pesaran, M. H., \& Potter, S. M. (1996). Impulse response analysis in nonlinear multivariate models. Journal of Econometrics, 74(1), 119-147. doi: https://doi.org/10.1016/0304-4076(95)01753-4

Kumar, M. (2013). Returns and volatility spillover between stock prices and exchange rates: Empirical evidence from IBSA countries. International Journal of Emerging Markets, 8(2), 108-128. doi: https://doi.org/10.1108/17468801311306984

Kutty, G. (2010). The relationship between exchange rates and stock prices: The case of Mexico. North American Journal of Finance and Banking Research, 4(4), 1-12.

Li, Y., \& Giles, D. E. (2015). Modelling volatility spillover effects between developed stock markets and Asian emerging stock markets. International Journal of Finance $\mathcal{E}$ Economics, 20(2), 155-177. doi: https://doi.org/10.1002/ijfe.1506

Lipka, M. (2017). Muslims and Islam: Key findings in the U.S. and around the world. Pew Research Center. Retrieved from https://pewrsr.ch/2vjIqxN

Lucey, B. M., \& Zhang, Q. (2010). Does cultural distance matter in international stock market comovement? Evidence from emerging economies around the world. Emerging Markets Review, 11(1), 62-78. doi: https://doi.org/10.1016/j.ememar.2009.11.003

Majdoub, J., \& Mansour, W. (2014). Islamic equity market integration and volatility spillover between emerging and US stock markets. The North American Journal of Economics and Finance, 29, 452-470. doi: https://doi.org/10.1016/j.najef.2014.06.011

Majdoub, J., \& Sassi, S. B. (2017). Volatility spillover and hedging effectiveness among China and emerging Asian Islamic equity indexes. Emerging Markets Review, 31, 1631. doi: https://doi.org/10.1016/j.ememar.2016.12.003 
Miniaoui, H., Sayani, H., \& Chaibi, A. (2015). The impact of financial crisis on Islamic and conventional Indices of the GCC countries. The Journal of Applied Business Research, 31(2), 357369. doi: https://doi.org/10.19030/jabr.v31i2.9171

$\mathrm{Ng}$, A. (2000). Volatility spillover effects from Japan and the US to the Pacific-Basin. Journal of International Money and Finance, 19(2), 207-233. doi: https://doi.org/10.1016/S0261-5606(00)00006-1

Obaidullah, M. (1999). Financial options in Islamic contracts: Potential tools for risk management. KAU Journal of Islamic Economics, 11, 3-26. doi: https://doi.org/10.4197/islec.11-1.1

Pesaran, H. H., \& Shin, Y. (1998a). Generalized impulse response analysis in linear multivariate models. Economics letters, 58(1), 17-29. doi: https://doi.org/10.1016/S01651765(97)00214-0

Pesaran, M. H., \& Shin, Y. (1998b). An autoregressive distributed-lag modelling approach to cointegration analysis. Econometric Society Monographs, 31, 371-413. doi: https://doi.org/10.1017/CCOL0521633230.011

Pindyck, R. S. (1984). Uncertainty in the theory of renewable resource markets. The Review of Economic Studies, 51(2), 289-303. doi: https://doi.org/10.2307/2297693

Rizvi, S. A. R., Arshad, S., \& Alam, N. (2015). Crises and contagion in Asia PacificIslamic v/s conventional markets. Pacific-Basin Finance Journal, 34, 315-326. doi: https://doi.org/10.1016/j.pacfin.2015.04.002

Rosly, S. A. (2008). Critical issues on Islamic banking and financial markets: Islamic economics, banking and finance, investments, Takaful and Financial Planning. Kuala Lumpur, Malayisa: Dinamas Publishing.

Sahar, N. U., \& Shah, Z. A. (2017). Stock market return and volatility spillovers: The case of selected Muslim majority countries. Journal of Islamic Business and Management, $7(1), 6886$.

Schoon, N. (2008). Islamic finance-A history. Financial services review. Retrieved from https://bit.ly/2TaO9CO

Shahzad, S. J. H., Ferrer, R., Ballester, L., \& Umar, Z. (2017). Risk transmission between Islamic and conventional stock markets: A return and volatility spillover analysis. $I n-$ ternational Review of Financial Analysis, 52, 9-26. doi: https://doi.org/10.1016/j.irfa.2017.04.005

Singh, P., Kumar, B., \& Pandey, A. (2008). Price and volatility spillovers across North American, European and Asian stock markets: With special focus on Indian stock market (WP;2008-12-04). Indian Institute of Management, Ahmedabad, India.

Susmel, R., \& Engle, R. F. (1994). Hourly volatility spillovers between international equity markets. Journal of International Money and Finance, 13(1), 3-25. doi: https://doi.org/10.1016/0261-5606(94)90021-3

Tabak, B. M. (2006). The dynamic relationship between stock prices and exchange rates: Evidence for Brazil. International Journal of Theoretical and Applied Finance, 9(08), 1377-1396. doi: https://doi.org/10.1142/S0219024906003974 
Theodossiou, P., \& Lee, U. (1993). Mean and volatility spillovers across major national stock markets: Further empirical evidence. Journal of Financial Research, 16(4), 337350. doi: https://doi.org/10.1111/j.1475-6803.1993.tb00152.x

Van Greuning, H., \& Iqbal, Z. (2008). Risk analysis for Islamic banks. The World Bank, Washington, DC, WA.

Walkshäusl, C., \& Lobe, S. (2012). Islamic investing. Review of Financial Economics, 21(2), 53-62. doi: https://doi.org/10.1016/j.rfe.2012.03.002

Yaqubi, N. (2000). Participation and trading in equities of companies whose main business is primarily lawful but fraught with some prohibited transactions. Paper presented at the Fourth Harvard Islamic Finance Forum, Harvard University, Cambridge, MA.

Zhao, H. (2010). Dynamic relationship between exchange rate and stock price: Evidence from China. Research in International Business and Finance, 24(2), 103-112. doi: https://doi.org/10.1016/j.ribaf.2009.09.001 